\title{
CHRONICA
}

\section{К 90-летию Михая Петера}

Мне выпала большая честь поздравить профессора Михая Петера с 90-летним юбилеем. Мы знакомы уже более 46 лет, с самого начала моих отношений с Будапештским университетом им. Этвеша Лоранда. Для меня символично, что профессор Петер был среди тех, кто принимал меня в Будапештский университет им. Этвеша Лоранда в 1972 г. и направил на поприще филолога. В 2010 г. Михай Петер присутствовал на моей защите диссертации на соискание степени доктора Венгерской академии наук, а теперь мне предоставлена возможность выразить ему поздравления и слова признания.

Михай Петер навсегда останется для меня уважаемым и любимым Учителем, но с начала 1980-х гг., когда после 4 лет преподавания в средней школе я вернулась на факультет гуманитарных наук, он стал и моим высокопочитаемым коллегой. В период с 1996 по 2016 гг., во время председательствования Михая Петера в Секции общего языкознания Венгерского лингвистического общества, я занимала при нем должность секретаря. Я считаю, что в течение этих 20 лет наш тандем работал очень хорошо: мудрость и трезвость суждений Михая Петера и мои организаторские инициативы прекрасно дополняли друг друга. Господин Учитель передал мне эстафету после назначения меня на пост председателя секции в 2017 г. Его деятельность на этом поприще продолжает служить для меня образцом, на который я равняюсь.

Поздравляя Михая Петера, я не могу не вспомнить о некоторых моментах из его жизненного и профессионального пути, хотя биографические факты ранее не раз озвучивались при чествовании юбиляра (например, ZOLTÁN 1998, NYOMÁRKAY 1999, Zoltán 2003, HetÉnyi 2008, Havas 2009, LADÁNYi 2013).

Михай Петер родился 8 ноября 1928 г. в Будапеште. Обучение в университете по специальности преподавателя английского и русского языков он начал в 1947 г. в предшественнике нашего университета, в Университете им. Петера Пазманя. Университетское образование наш юбиляр продолжил по стипендии в Ленинградском государственном университете им. А. А. Жданова на факультете русского языка и литературы, где в 1954 г. с отличием защитил диплом. С 1954 по 1956 гг. (уже в Будапеште) он занимал должность младшего преподавателя в действовавшем в те времена Институте им. В. И. Ленина, а с сентября 1956 г. вплоть до выхода на пенсию (и даже после, в звании профессора-эмеритуса) был преподавателем кафедры русского языка и литературы на факультете гуманитарных наук Будапештского университета им. Этвеша Лоранда, где с 1956 г. работал в качестве младшего преподавателя, с 1959 г. - адъюнкта, в 1967 г. продолжил свою деятельность в звании доцента, а с 1985 г. - профессора. Начиная с 1981 г. в течение более 10 лет Михай Петер занимал должность заведующего кафедрой русского языка и литературы, а также долгие годы редактировал издаваемый кафедрой научный журнал Studia Russica. Наряду с этой деятельностью в период с 1978 по 1991 гг. он возглавлял и кафедру славянской филологии, а с 1972 по 1978 гг. исполнял функции заместителя декана факультета гуманитарных наук. 
Процесс становления научных интересов Михая Петера определялся как его значительными и влиятельными публикациями, так и достижениями в соискании научных степеней; темы защищенных диссертаций раскрывают всю широту исследовательских интересов ученого. В 1959 г. он защитил магистерскую диссертацию Об интонации русских вопросительных предложений. Темой диссертации на соискание степени кандидата наук в 1965 г. стало творчество Твардовского (Поэтический язык поэм Твардовского). В 1988 г. после защиты диссертации на тему Языковые средства и способы выражения эмоций нашему юбиляру была присвоена степень доктора лингвистических наук (последние две диссертации вышли в свет в виде монографии в 1970 г. и в 1981 г.).

Как уже ранее не раз отмечалось почитателями таланта Михая Петера, на протяжении своего профессионального пути он, как исследователь, и как преподаватель, занимался многочисленными изысканиями в различных областях филологии - от фонологии и грамматики до стиховедения и различных функций языка (cp. РÉTER 1998). При этом не раз появлялась идея связать проблематику языкознания и литературы, которую Михай Петер успешно воплощал в своих работах. И это не случайно, ведь именно интерес к литературе привел его, как и многих из нас, к языковедческим исследованиям. Как отмечает наш юбиляр в сборнике О лингвистике - в первом лице единственного числа и в посвященном ему 52-м номере серии Путь в профессии и собственные признания венгерских лингвистов (см. BOLLA 1998): «Другой большой стимул к „открытиям“ в языке исходил со стороны литературы. Замечательный венгерский ученый Аладар Комлош был моим учителем в гимназии, именно он привил мне интерес к творчеству великих лириков, сплотившихся вокруг журнала Nyugat [Запад]» (Ре́TER 1991: 206).

Личность Михая Петера как человека и исследователя точно характеризуется отрывком из сборника О лингвистике - в первом лище единственного числа. На вопрос «Какие черты характеризуют лингвиста?» Михай Петер дает следующий ответ: «Прежде всего те, которые характерны для каждого представителя науки: уважение к фактам, неустанное стремление к постижению скрывающихся за явлениями закономерностей и осознание того, что именно это стремление руководило и руководит всем и всеми; непритупляемое чувство самокритики; восприятие науки как безусловного процесса познания и т. д. Каковы же другие отличительные черты лингвиста? В первую очередь, осознание того, что предмет его науки является исключительным родовым атрибутом Человека, самой распространенной формой человеческого бытия. Лингвистика - это ориентированная на человека наука, а лингвист - в отличие от ученого-естественника или математика - антрополог в самом широком смысле слова» (РЕ́TER 1991: 206).

Действительно, все перечисленные особенности - уважение к фактам, поиск закономерностей, критичность мышления, уважительное отношение к придерживающимся иных суждений соратникам, восприятие науки как безусловного процесса познания и толкование человеческого языка как антропологического явления - являются важными характеристиками личности ученого Михая Петера.

Благодаря своим собственным убеждениям и, возможно, функциональному подходу к основательно изученной им деятельности Пражской школы, Михай Петер стал одним из первых, кто уловил альтернативные устремления, разворачивающиеся против формальной лингвистики.

Признавая роль генеративного и постгенеративного направлений в исследованиях проблематики «речевое высказывание - исключительно человеческая деятель- 
ность» должно дополняться «возможностями языкового общения между человеком и машиной», Михай Петер уже в 1991 г. проницательно заметил, что «для раскрытия проблематики „компьютер как смоделированный человек“ и „человек как компьютер“" необходимо прояснить те стороны структуры и функционирования естественного человеческого языка, которые противостоят формализации и математическому и /или логическому подходу. Не случайно, что в последние десятилетия параллельно с генеративным и постгенеративным направлениями в науке о языке сформировались и начали бурно развиваться такие области, как психолингвистика, социолингвистика, лингвистическая прагматика, теория речевого акта и когнитивная лингвистика, исследующие естественное употребление языка с учетом рассмотрения контекста речи, фоновых знаний, различных невербальных кодов и инструментов» (РÉTER 1991: 210-211).

Характеристику нашего юбиляра я хотела бы дополнить словами из поздравления по случаю его 80-летия, написанного Ференцем Хавашем:

«Многие из нас - лингвисты, многие - литературоведы. Но каждый ли может назвать себя филологом? Михай Петер - однозначно да. Речь идет не только о том, - хотя это на самом деле поразительно, - что размах его научной деятельности простирается от исторического и описательного языковедения до общего языкознания; исследовательский интерес ученого охватывает круг тем фонетики, лексикологии, стилистики, теории перевода, поэтики и целого ряда других дисциплин. Речь идет о том, что в исследованиях и научных выводах Михая Петера эти аспекты совмещаются, осуществляясь одновременно. То, что выдвигается темой в одной из его работ, в действительности всегда выделяется из общей филологической культуры и обосновано научным спросом и интеллектуальным интересом» (HAVAS 2009: 123).

Наряду с исследовательским интересом Михая Петера, охватывающим широкий спектр взаимосвязанных тем, следует подчеркнуть свежесть и гибкость, характеризующие его мышление по сей день. Эта свежесть и гибкость мышления означает то, что в его научных лингвистических работах всегда достигаются новые результаты как по основным направлениям исследований славянской или венгерской лингвистики и литературы, так и в других смежных науках (от философии до эстетики и этологии). Свежесть и гибкость в отношении нашего юбиляра означают также и то, что с течением времени он всегда остается готовым включить новые темы в свои исследования, будь то анализ стихотворений Д. Варро (см. статью Airwave leheletü Szulamit - PÉTER 2008b), или же - как в изданной в 2012 г. его книге - анализ проявлений в языке карнавальности и мистификации.

Меня восхищает и способность Михая Петера на основе своих обширных знаний описывать явление в его мельчайших подробностях и создавать при этом всеобъемлющую картину, извлекая из нее те элементы, из которых он затем выстраивает собственные идеи (см., например, статью о венгерском глагольном виде - PЕ́TER 2008a). Эта способность является существенной чертой Михая Петера не только как исследователя, но и как педагога. Исходя из всего этого, само собой разумеется, что я говорю о Михае Петере не только как об Учителе поколений, но и прежде всего, конечно же, на основе своих личных впечатлений.

Как я уже упоминала об этом ранее, господин профессор Михай Петер сопровождает меня на моем пути в профессии самого начала и по сей день. В 1972 г. он заседал в той приемной комиссии, по решению которой осенью того же года я смогла начать обучение на отделении венгерской и русской филологии факультета гуманитарных наук Будапештского университета им. Этвеша Лоранда. В небольшой группе 
на русском отделении наш юбиляр сначала вел семинар по старославянскому языку, а затем по истории древнерусского языка. Занятия Учителя были очень требовательными. Я вспоминаю о нем как об уважаемом и любимым до преклонения нашем преподавателе, к урокам которого стыдно было не подготовиться. Даже мои интересующиеся литературой однокурсники соглашались, что невозможно не выполнять задания и приходить неподготовленными на его уроки. Учитель до сих пор помнит об успехах ставшей благодаря его подготовке группы отличников, вспоминает каждого из студентов, но я думаю, что он никогда не задумывался о том, что успехи группы на этих занятиях явно вдохновлялись его превосходством, требовательностью, уважением и любовью к нему, которые он вызывал в нас.

Через несколько лет после окончания университета я испытывала похожие чувства и тогда, когда завершив 4-летнюю работу в качестве учителя профессионального училища, я попала на кафедру общего и прикладного языкознания, в возглавляемую Яношем Жилкой исследовательскую группу Диалектика форм движений в языке. В связи с этим мне пришлось пройти обучение на отделении общего и прикладного языкознания, в программу которого входили, в частности, семинарское занятие и лекция по фонологии, изучавшейся в те годы в течение двух семестров. Этот предмет вел профессор Михай Петер. Курсы по фонологии в принципе являлись частью обязательной учебной программы второго года обучения, но поскольку я параллельно обучалась по программам первого и второго года, мне надо было сдать фонологию на первом курсе. Это стало настоящим испытанием моих способностей к учебе, к тому времени слегка поблекших под влиянием учительской работы в профессиональном училище. Я помню чувство боязни того, чтобы не дай бог вызвать разочарование собой у профессора Михая Петера. (И конечно же, я помню, как я собирала в кулак всю свою волю и стремление утвердиться в науке, стимулировавшее меня к усиленным занятиям наукой.)

Говоря о профессоре Михае Петере как о преподавателе нельзя забывать и о том, что он поддерживал своих учеников не только в начале их обучения в университете и тернистого пути в науке. И в дальнейшем, на протяжении многих лет он внимательно следил за профессиональным становлением - в том числе и моим своих учеников и молодых коллег, помогая во всем. Подобное отношение у него было и к остальным коллегам. Иштван Ньомаркаи в поздравлении Михая Петера с 70-летием отмечает: «Множество его публикаций появилось в сборниках, изданных в честь венгерских исследователей. Эти хорошо продуманные, всегда оригинальные, остроумные замечания показывают, что их автор не только наблюдал за работой своих современников, но и проявлял особый интерес и внимание к ним» (NYOMÁRKAY 1999: 124).

Я счастлива, что в строки торжественных поздравлений по случаю 90-летия Учителя Михая Петера я могу включить слова признания от себя лично, от имени моих современников и молодого поколения филологов. Благодарим профессора Петера за то, что он с нами, и как педагог и исследователь продолжает вдохновлять нас на новые достижения.

Научные труды Михая Петера и его методические публикации являются важными отправными точками для лингвистических исследований и преподавания как в славянском, так и в венгерском и общем языкознании - в фонетике, фонологии, грамматике и стилистике. Среди множества значительных публикаций профессора Петера мы выделим две его работы: основополагающую монографию 1991 г. Языковые средства и способы выражения эмоччий, и написанный в 1969 г. и несколько 
раз переизданный учебник Историческая грамматика русского языка, по которому обучались целые поколения филологов-русистов. Я также использую научные результаты Михая Петера не только в исследованиях (например, в связи с аспектом глагола, cp. РÉTER 2008a), но и в преподавательской практике: в списке специальной литературы моего курса лекций по Теории языка, который и в настоящее время ведется в программе магистратуры, к обязательным произведениям относится работа профессора, рассматривающая синхронную и диахроническую концепцию Пражской школы функциональной лингвистики, а также занимающаяся сравнением взглядов Фердинанда де Соссюра и Бодуэна де Куртенэ (ср. РЕ́тER 2006).

Десять лет назад, 28 ноября 2008 г. профессор-эмеритус Михай Петер был награжден фондом «За русский язык и культуру» премией «Лучший русист» за многолетнюю выдающуюся деятельность в науке и сфере высшего образования.

Однако в 2008 г. не закончилась научная деятельность профессора. Профессор Михай Петер и в течение последнего десятилетия непрерывно работает и публикуется, занимаясь разработками как старых тем, так и новых, на которые у него до сих пор не было времени (например, сборник Мои русские стихи. Материаль для планируемого семинара по поэтике - РЕ́TER 2016, или же уже упомянутая книга Разоблачающий язык. Карнавализаџия и мистификация в речевом употреблении и словарном отражении - PÉTER 2012).

Надеюсь, Учитель простит меня за то, что я процитирую строки из его письма ко мне, повествующего о его пенсионных годах: «Что касается выхода на пенсию, то это не только завершение одной эпохи жизни, но и начало нового ее этапа, с новыми планами и новыми радостями. Сошлюсь на собственный пример: я уже 18 лет на пенсии, но мне не довелось скучать и полдня. Большая помощь для меня - это моя жена Илона, которая нежно похлопает меня по спине, когда я просто устал. Также важно, что я как-то могу поддерживать моих дочерей и внуков... Мне дает силы и то, что я могу наблюдать за становлением из судеб...».

Я желаю нашему Учителю Михаю Петеру крепкого здоровья на все последующие годы, множество счастливых мгновений от общения в кругу семьи, а также стойкого желания вести исследовательскую работу по своим интересам и в свое удовольствие - и даже смело начинать исследования новых тем!

Мария Ладани

\section{Литература}

BollA 1998 = Bolla Kálmán (szerk.): Magyar nyelvész pályaképek és önvallomások 52. Péter Mihály. Budapest: ELTE Fonetikai Tanszék, 1998.

HAVAS 2009 = HAVAS Ferenc: Péter Mihály 80 éves. Magyar Nyelv 105 (2009): 122-126.

HetÉnYI 2008 = HetÉnYI Zsuzsa: К 80-летию Петера Михая. Studia Slavica Hung. 53 (2008): $248-249$.

LADÁNYI 2013 = LADÁNYI Mária: K 85-летию Михая Петера. Studia Slavica Hung. 58 (2013): 232-234.

NYOMÁRKAY 1999 = NYOMÁRKAY István: Péter Mihály hetvenéves. Magyar Nyelv 95 (1999): 123 124.

PÉTER 1991 = PÉTER Mihály: „Nihil linguistici a me alienum putat”. In: BAKRÓ-NAGY Marianne, KONTRA Miklós (szerk.): A nyelvészetröl - egyes szám első személyben. Budapest: MTA Nyelvtudományi Intézet, 1991. 205-212.

PÉTER 1998 = Péter Mihály tudományos publikációi. In: ZolTÁN András et al. (szerk.): Nyelv, stílus, irodalom. Köszöntö könyv Péter Mihály 70. születésnapjára. Budapest: Argumentum, 1998. 7-13. 
PÉTER 2006 = PÉTER Mihály: Szinkrónia és diakrónia a prágai iskola felfogásában. Magyar Nyelv 102 (2006): 400-407.

PÉTER 2008a = PÉTER Mihály: A magyar aspektusról - más aspektusból. Magyar Nyelv 104 (2008): $1-11$.

PÉTER 2008b = PÉTER Mihály: Airwave leheletü Szulamit. Mozgó Világ 34/9. http://epa.oszk.hu/ 01300/01326/00103/MV 200809 06.htm.

PÉTER 2012 = PÉTER Mihály: A leplező nyelv. Álcázás és ámítás a nyelv használatában. (Az ékesszólás kiskönyvtára 22.) Budapest: Tinta Könyvkiadó, 2012.

PÉTER 2016 = PÉTER Mihály: Orosz verseim. Egy tervezett költészeti szeminárium anyagai. Szerkesztette Hetényi Zsuzsa. (Dolce Filologia XVI.) Budapest: ELTE BTK Irodalomtudományi Doktori Iskola, 2016.

ZoLTÁN 1998 = ZoLTÁN András: Péter Mihály hetvenéves. In: ZolTÁN András et al. (szerk.): Nyelv, stílus, irodalom. Köszöntö könyv Péter Mihály 70. születésnapjára. Budapest: Argumentum, 1998. $5-6$.

ZoltÁN 2003 = ZoLtÁN András: K 75-летию Петера Михая. Studia Slavica Hung. 48 (2003): $472-$ 474.

\section{Attila Hollós Celebrating His 85th Birthday}

Born in Szombathely, in the Transdanubian region of Hungary, on 5th August 1933, the eminent Hungarian Slavist Attila Hollós, maintaining his position for several decades as the technical editor of the journal the reader is holding in his hands, is celebrating his 85th birthday this year.

The book entitled The Old Slavonic Language, a result of co-authorship, remains his major work, in which two main sections, i.e. chapters on descriptive phonetics and syntax summarise his own findings, providing examples gleaned from Codex Zographensis and Codex Assemanius. This specialist work reveals fine acumen combined with a systematic approach. Attila Hollós is the author of numerous university coursebooks and monographs, two of which have been republished several times, the co-author with Larisa Stankevich of the first Hungarian-Belarusian Dictionary, which came out in Nyíregyháza in 2007 after his retirement, a leading scholar in the field of the history of the Old Church Slavonic language and also the history of the Russian language, delving into etymology, which demands a broad spectrum of interdisciplinary innovation. During his academic career, he has contributed a great deal to the research being done into Hungarian-Russian language contacts. His career as a scholar and university lecturer exemplifies how the ideal blend of excellent classical training and academic environment can benefit science.

A Hungarian citizen with significant Slavic traits (his family had partially come from the Upper Region of pre-Trianon Hungary, thus the Slovak language was in frequent use as a second dialect), Attila Hollós spent his summer holidays in a Slovakian village in his early childhood, so the acquisition of the language came with ease. In the chaotic aftermath of World War II, he found himself together with his family in the vicinity of BergenBelsen under occupation in the British zone of Germany. It was here that he embarked on taking private lessons in Russian. His tutor happened to be an engineer, a refugee from the Baltic region, having chosen to flee from the Red Army. He taught the young boy in return for food. Upon return to Hungary, the family was held at a checkpoint camp in Kaposvár in October 1946 for a while, consequently taking up residence in Budapest, where the father filled a lecturing position at Kossuth Army Academy. Despite post-war hardships, in the meantime Attila Hollós excellently passed his private exam in the capital's prestigious and 
famed institution of secondary education called Alley Lutheran Grammar School, an alma mater long renowned for graduates who later became Noble Prize winners. He continued to learn at Archbishop's Grammar School located in the castle district, seriously damaged due to the bombings. This school, later renamed after Prince Ferenc Rákóczi II, provided undergraduates with high standards of training thanks to the laborious strife of the director, a scholar himself. Besides mastering Latin, Old Greek, and English, Attila Hollós could resume his Russian studies after the subject was introduced in the curriculum. Thus, this experience has led him to devote himself to Slavonic studies. In a private interview given to the author of this congratulatory note, who can pride himself on having attended his lectures and seminars at the Eötvös Loránd University of Budapest in the early 1990s, the scholar also specially addressed his indebtedness to his mother, who would make every effort - she herself spoke several languages fluently - to stimulate her son's future career as a linguist. Having passed his maturity exam in 1952, Attila Hollós applied for admission to the Lenin Institute. Functioning in loose cooperation with the University of Budapest, it was at that time practically the only institution of higher education in charge of training and turning out teachers of Russian in the capital city.

During his university years, his intellectual thirst was nurtured by Emil Baleczky, the internationally renowned linguist, who had earned a fellowship at Charles University in Prague. This scholarly workshop, a centre for Slavonic studies in the region by that time, whose reputation was also remarkably enhanced by the boom in general linguistics, was galvanized by the spirit of the Prague Linguistic Circle and its breakthrough towards an alternative approach to the language. Due to his special professional interests, Baleczky is supposed to have been influenced by Miloš Weingart, whose methodology undoubtedly owed a great deal to the Prague Circle, which he belonged to. A disciple of Professor Emil Baleczky, Attila Hollós progressively fashioned his research career as a linguistic historian along similar lines. In 1956, he received a post at the Teachers' Training College in Eger, in the northern part of Hungary, while simultaneously filling a teaching position in Kál at the general secondary grammar school until his appointment as a lecturer at the Department of Russian Language and Literature at the Eötvös Loránd University of Budapest in 1961. His aspirations were met with hearty support on behalf of Professor Baleczky. Colleagues at the Department, especially Erna Páll, a bright researcher dealing with descriptive linguistics, focusing her studies on topical issues of syntax, as well as Mihály Péter, later a professor emeritus, sharing an ardent interest in scrutinizing the history of the Russian language, appeared to provide a creative and inspiring environment, due to which an outstanding workshop came to being.

Here, his scholarly career came into full bloom, progressing rapidly and smoothly, which is best highlighted by two doctoral dissertations in 1991 and 1993, both related to lexicography. Via completing these studies, he filled a gap of cardinal importance in this field of study, by compiling an exhaustive corpus of borrowings from Hungarian into the Russian language. Proceeding to work with Emil Baleczky, he had earlier become the coauthor of the aforementioned reputable edition of The Old Slavonic Language, first printed in 1968, a milestone in domestic Slavonic studies, republished five times. As a university course-book, it greatly benefited students of Russian as well as other Slavonic languages for long decades, serving, first and foremost, as a springboard for generations of experts engaged in investigating a wide scale of problems in Slavonic and Russian diachronic linguistics, following into the footsteps of Attila Hollós. Furthermore, his worthy contributions to compiling bibliographies in Russian linguistics as well as an index to Studia Slavica Academiae Scientiarum Hungariae, are highly valued by today's professional community 
as key sources and databases assisting future research. His innumerable merits in the field of linguistics are objectively measured at their true value in an extensive survey included in a congratulatory note paying honour to Attila Hollós, written by András Zoltán in the 48th volume of this journal.

In addition to doing scholarly investigations and maintaining a university lecturer's position, Attila Hollós' other facet of activities is clearly demonstrated in the numerous volumes of Studia Slavica Academiae Scientiarum Hungariae since he was involved in editing this journal. He was, in fact, acting as a 'spiritus rector' of this periodical, as András Zoltán put it. Time-consuming responsibilities as required by the job of the technical editor were most flawlessly and accurately performed, including the tasks of proofreading, inviting, and collecting articles from authors. He remained a member of the editorial board even after refraining to carry on with technical editing.

Nonetheless, his retirement from teaching in 2001 was marked by a splendid renewal in his career as a researcher and editor. The year 2004 saw the publication of his most informative monograph in Hungarian, rich in presenting facts and filling a blank page in the history of Slavonic peoples. It is dedicated to the scrutiny of László Csopey's unrevealed oeuvre, an outstanding Sub-Carpathian Slavist who lived at the turn of the 19th and 20th centuries, a very early scholar of the Rusyn language, the author of a Russian-Hungarian Dictionary. While creating superb translations of Turgenev, Gogol, Leo Tolstoy as well as popularizing Russian literature among contemporary Hungarian public in this way, Csopey was also responsible for compiling language textbooks and schoolbooks. At the same time, Attila Hollós also offered a selection of Church Slavonic texts dating from the period of the 15th to 19th centuries. This research resulted in compiling a noteworthy chrestomathy published in Nyíregyháza (co-edited by Lajos Szőke). A major project aimed at bringing out a substantial volume (of close to 660 pages), a Festschrift under the title Sub Rosa. In honorem Lenae Szilard, to mark the jubilee of a prominent expert on Symbolism and particularly the Silver Age of Russian culture, may not have been accomplished, had it lacked the meticulous editorial work rendered by Attila Hollós.

A recent comparative analysis of the outcome of research conducted by Attila Hollós and Iván Horváth into the theory of loanwords is offered in a 2015 representative guide entitled Русский язык в Венгрии. Научные иссделования, written by V. A. Fedosov. This book undertook the task to give an outline of the works of Hungarian professionals engaged in Russian linguistics. A philologist in the very genuine, traditional, and real sense of the word, Attila Hollós up to now has never resented his work. His latest study presents novel achievements which appeared in a collective monograph published in memoriam Danuše Kšicová, the late Brno scholar, in Moscow in 2017. This thought-provoking paper facilitates the first insight into Csopey's lifework, hitherto a terra incognita for Russian scholars.

György Zoltán Józsa 